\title{
On the mechanisms of endogenous synthesis of xanthurenic acid a possible cause of human diabetes mellitus
}

\author{
Meyramov GG*, Meyramova-Abdraimova AG, Shaybek AS and Family Diabetes Research Group \\ Family Diabetes Research Group, Karaganda, Kazakhstan
}

In 1935 Musajo L. and coll. reported about synthesis of Xanthurenic Acid (XA). This chemical was separated from urine of experimental animals and identified as 4,8-digidroxyquinolin-2-xarboxylic acid, a derivative of 8-oxyquinoline [1] Formula: C10H7NO4.

This product interested by group of Lepkovsky S [2] Containing on diet enriched by fatty acids and tryptophan in the deficiency of vitamin B6 (pyridoxine) accompanied by intensive endogenous synthesis of XA in tissue. It was followed by developing of symptoms of diabetes in animals [3-8].

$\mathrm{XA}$ is a product of disturbances of Tryptophan metabolism, in routine conditions is metabolised on serotonin and kinurenin ways (Figure 1) which at the same time come to the end with a forming of a 5-oxyindol-acetic acid and NADF $[9,10]$. The deficiency of pyridoxal-5-phosphat (P-5-F) result inhibition of 5-oxytryptophan decarboxylase and of kinureninase that accompanied by inhibition of metabolization on both paths. As result 4 substances are formed: $\mathrm{XA}$ and 8 oxyquinaldine - from 3-oxyquinurenin and kynurenic and oxyquinurenic acids from kynurenin [10-12]. On the chemical structure $\mathrm{XA}$ is belong to derivatives of 8-oxyquinoline, a diabetogenic zinc-binding chemicals (DZC).

Main enzymes for synthesis of XA are kinureninaminotransferase and oxykinurenine tryptophan decarboxylase, a coenzymes of P-5-P $[10,13]$. XA is formed from 3-oxykynurenin. Under influence of kynu- reninaminotransferase from 3 oxykynurenin XA is formed. In the deficiency of P-5-P synthesis of serotonin is decrease and synthesis of XA and of kynurenine acid is increased [2,14]. However, there is, apparently, a contradiction: why deficiency of P-5-P inhibite synthesis of serotonin and stimulate synthesis of XA? On the one hand this results based on fact that the pyridoxal enzymes of tryptophan metabolism differently react to deficiency of P-5-P: if activity of a kynureninase decrease by $83 \%$, then of kynureninaminotransferase decrease for only $42 \%[13,15]$. On the other hand, studying of localization of enzymes in cells of liver and kidneys it was established that the kynureninaminotransferase is both in mitochondria and in soluble part of cells whereas a kynureninase - only in a soluble part of cells. In the deficiency of P-5-P in organism the content of these two enzymes in soluble part of cells significantly decrease, and mitochondrial kinureninaminotransferase remains at the previous level [16]. Increasing of excretion with urine of XA is explained by it. For the first time the high amount of XA were found in the urine of the white rats who were contained on diet enriched with tryptophan and in deficiency of vitamin B6.

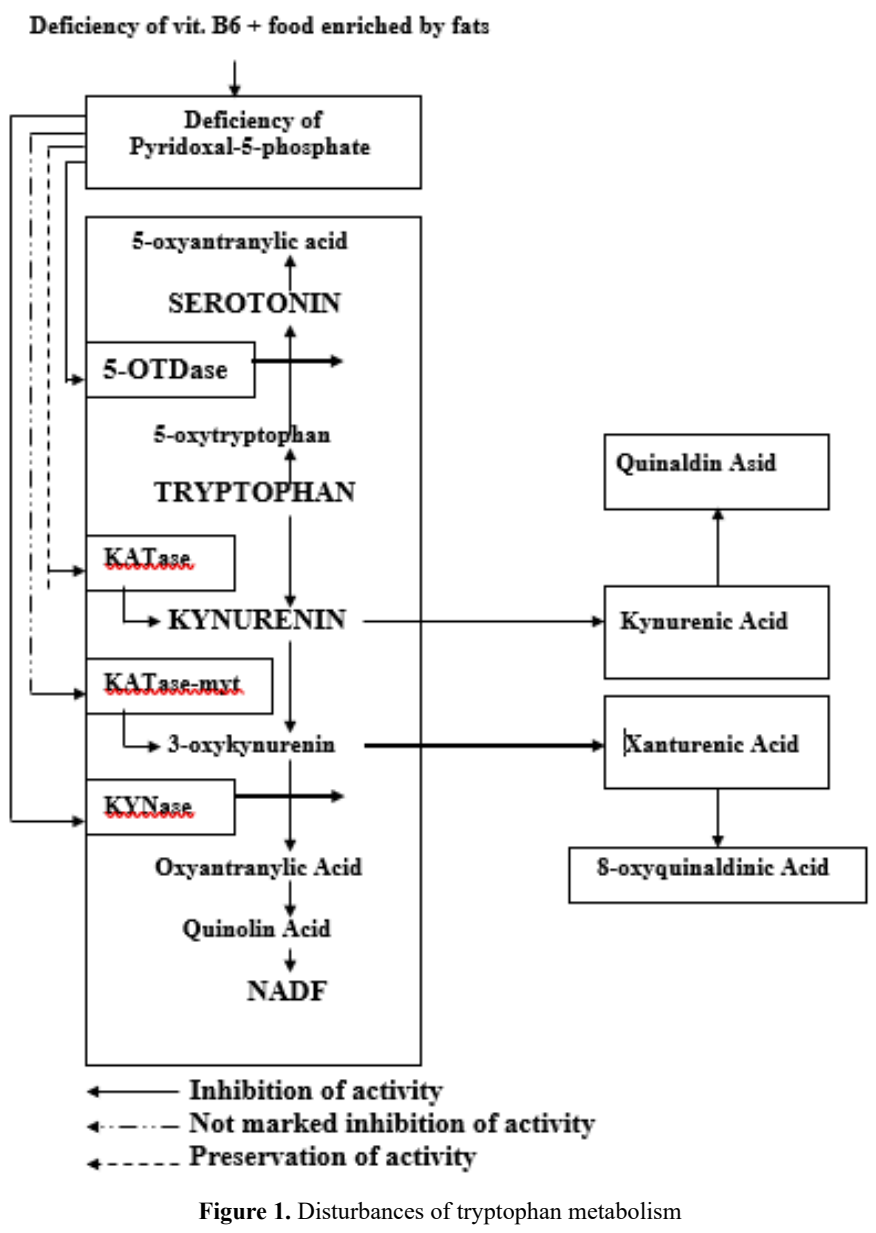

5-OTDase: 5-tryptophanedehydrogenase; KATase: Kynurenine aminotransferase; KATase myt: Kynurenine aminotransferase mytochondrial; KYNase: Kynureninase

Addition of Pyridoxine accompanied by disappearance of XA from urine $[9,12,17]$. However, marked avitaminosis of B6 result decrease of activity of kynurenin amino transferase that accompanied by decrease

${ }^{\star}$ Correspondence to: Meyramov GG, Family Diabetes Research Group, Karaganda, Kazakhstan, E-mail: meyramow@mail.ru

Received: January 31, 2019; Accepted: February 25, 2019; Published: February 27, 2019 
of its excretion with urine [18]. Later XA was found in urine of rabbits, dogs, guinea pigs and human [3,11,19-22]. Increasing of excretion of $\mathrm{XA}$ with urine is revealed at elderly patients with diabetes mellitus. At elderly people [23] there are increase amount of XA and of kynurenic acids in urine. In spite of the fact that administration of Pyridoxin result decreasing of concentration of XA in urine, this is not a complete normalization of their excretion [23]. Average concentration in daily urine at healthy persons fluctuates from $2,1 \mathrm{mg}$ to $8,8 \mathrm{mg}$ [12]. Deficiency of P-5-F in organism developed as result of deficiency of vitamin B6 and as result of inhibition of synthesis of P-5-P from vitamin B6. Synthesis of XA is increased using of diet enriched by saturated fatty acids and casein. Two enzyme systems are known which provide biosynthesis of P-5-F: pyridoxynphosphatoxydase (PPO) and pyrido- xinkynase. The diet enriched by fatty acids, stimulate decrease of activity of PPO in liver [24] which can be restored by administration of vit.B2, a coenzyme of PPO. Studying of disturbances of tryptophan metabolism depending on age of patients showed that in the first four days of life derivatives of kynurenine not found in the urine of new-borns [25].

During the period from the 5th to the 20th day of life there are a minimal concentrations of XA. Administration of a-tryptophan does not increase excretion of XA $[26,27]$, but increase it at children at age of 4-6 years [28]. In patients age 70 years and over formation of kynurenin is increased. Administration of $100 \mathrm{mg} / \mathrm{kg}$ of a-tryptophan accompanied by marked excretion of XA. Administration of pyridoxine result normalization of excretion at elderly people [29]. There are a changes of tryptophan metabolism at pregnant women [30-32]. Administration of a-tryptophan accompanied by active excretion XA with urine [33-35]. Administration of a-tryptophan, $100 \mathrm{mg} / \mathrm{kg}$ at pregnancy was followed by increasing excretion not only of XA acid but also of kynurenine acid [36].

At the same time, the increase of excretion of XA found within all period of pregnancy and increase excretion of kynurenic acid was observed in the first 3 months [36]. A high excretion of XA at pregnant women was decreased after administration of Pyridoxine [33-34]. The increased excretion of XA- is a symptom of deficiency of vitamin B6 in patients with diabetes $[37,38]$. Very often disturbances of Tryptophan metabolism are shown as dissociation of Tryptophan accompanied by forming of a large amount of XA. Deficiency of P-5-P in result developing of disturbances of Tryptophan metabolism [14].

Kotake Y in 1957 [4] investigated processes of formation and of excretion of XA in organism. He used administration of various sodium salts of fatty acids and of Tryptophan. The most marked effect of endogenous synthesis and excretion with urine of XA - as 10,49 of mg daily - was showed using of complex as Tryptophan+oleinic acid. The least effect - 1,6 mg - past using of Tryptophan only. Excretion of XA after administration of Tryptophan in combination with fatty acid: Tryptophan+acetate - 5,37 mg; Tryptophan+propionic acid - 8,79 mg; Tryptophan+oil acid - 9,87 mg; Tryptophan+valerenic acid - 9,64 mg; Tryptophan+palmitic acid - 9,61mg Tryptophan+stearic acid of 8,57 $\mathrm{mg}$.

The specific diet stimulate endogenous synthesis of XA acid was recommended by Kotake Y [4]. Percentage of components of diet: casein-22, salt mixture McCollumn-6, agar-agar-3, yeast - 2, oil - 10, sugar-5, amylum-52. This diet include the majority of above-named fatty acids in the structure and each diet caused increasing of excretion of XA with urine by 3,5-6,5 times in compared with diet contain only Tryptophan. It was showed that biosynthesis of P-5-P depends of content of fat or fatty acids in food. And as conclusion: diet enriched by fats result decreasing of activity of pyridoxalaminotransferase in liver
[24]. Due to acceleration of kynurenine way of Tryptophan metabolism its diabetogenic metabolites can collect at a stress $[39,40]$.

Meanwhile injection of vitamin B6 10,0 mg in experimental conditions result decreasing of excretion of XA till 2,03 mg [41] per $24 \mathrm{~h}$ in compared with 8,42 mg without vitamin B6. Kotake Y in 1968 established that fatty acids suppress synthesis of P-5-P that result more active endogenous synthesis of XA. Intraperitoneal administration to mice of $200 \mathrm{mg} / \mathrm{kg}$ of endogenous formed XA followed by developing of diabetes $[42,43]$. It was showed a temporary hyperglycemia at rabbits after administration of XA [44]. However, synthetic XA did not caused developing of diabetes in dogs and rabbits [45].

At the same time, a large amount of fat in diet in combination with XA or Kynurenic acid followed by hyperglycemia and developing of histologic changes typical for the experimental diabetes [10,46-48]. Meanwhile disturbances of carbohydrate metabolism not developed in rats and rabbits after administration of XA or containing of animals on free of vitamin B6 diet [49]. Using of diet contains Tryp- tophan,10 $\mathrm{mg} / \mathrm{kg}$ in combination with hypovitaminosis of B2 [4] was followed by developing of hyper- glycemia and xanturenuria. At rats contained on diet by Kotake Y glycemia is increased for long period that accompanied by glucosuria and polyuria. Animals had a tendency to increase of body weight, on average from $140 \mathrm{~g}$ to $220 \mathrm{~g}$ and until $260 \mathrm{~g}$ (obesity) as of xanturenuria for $2-3 \mathrm{mg} / 24 \mathrm{~h}[50,51]$.

It was established that increase of blood glucose level besides XA acid is caused by kynurenic acid [52] which final products is quinaldinic acid [53]. In our experiences with using within 3 months of a diet of Kotake $\mathrm{Y}$ also permanent increase in level of a glycemia was revealed which was, however, less expressed in comparison with observed after single-pass administration of diabetogenic doses of other derivatives 8-oxyquinolines. Its influence by the end of experience was followed also marked - at 7-10 times - increasing of xanthurenuria and decreasing of insulin content in B-cells. XA is transformed in 8-oxyquinaldinic acid [17] which possess diabetogenic properties. Other metabolites of Tryptophan as hinaldinic and kynurenic acids possess have insulin releasing activity $[17,50]$. It is shown a large release of insulin from the isolated islands at the first $30 \mathrm{~min}$. after the beginning of incubation.

Results of investigation of state of gist structure of pancreas in experienced animals: vascuolisation and destruction of cytoplasm, gydropic distrophya, destruction of nuclei [4,5,54-57]. It was established that increase of blood glucose level besides XA is caused by kynurenic acid [58] which final products of metabolism is quinaldinic acid [53].

Presence of quinaldinic acid almost completely suppresses the second phase of release of insulin [59]. Incubation of insulin and XA acid result forming of stable complex $[51,60]$. By using of fluorometric methods it was showed that two moles of XA connected with one insulin dimer. Hormonal activity of this complex decrease until $49 \%$ of activity of native insulin $[51,61]$ and is increased past administration in media of Zinc [60,62].

Murakami E. [63-65] showed that incubation of XA with insulin result formation of two complexes. In one of them insulin is bound to 1 mole of XA acid and in another - with 1,5 mole. XA easily formed complexes with insulin in blood serum, without breaking structure of insulin. This complexes are stable [51]. It is supposed that connection is carried out between atom of Zinc and imidazole radical in a molecule of insulin [51,43]. XA shows a high affinity for ions of Zinc [66]. Activity of insulin is restored after addition of ions of Zinc to blood serum contains of complex XA-insulin [67]. 


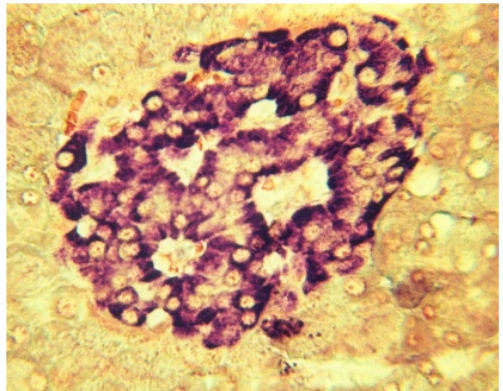

1

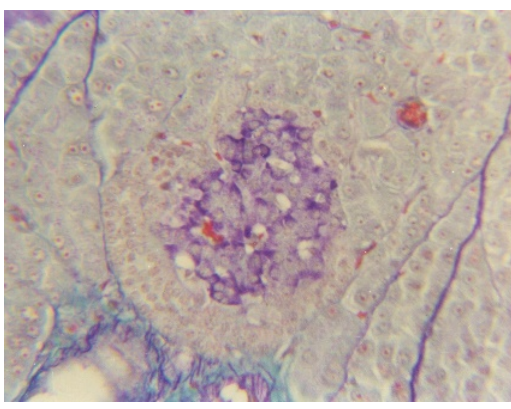

2

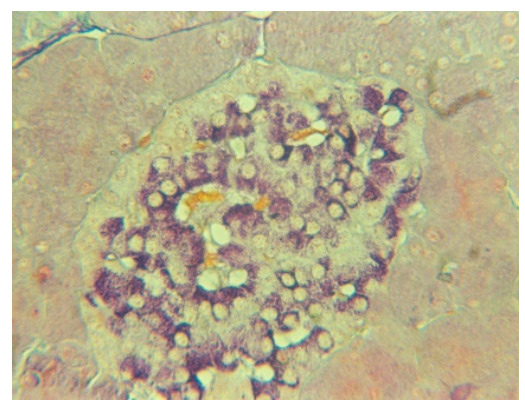

3

Figure 2. Histostructure of pancreatic islets in diabetes caused by DZC and by XA. [1) intact animal: histostructure and insulin content (violet color) without changes in $\beta$-cells. 2) heavy diabetes caused by DZC: destruction and death of majority of $\beta$-cells, by deformation and a decrease of the size and number of islets, a marked decrease of insulin content in $\beta$-cells developed very rapidly within 3-5 days. 3) diabetes caused by XA is developed more slowly, the number and size of the islands do not change at first destruction and cell's death developed gradually not so marked decrease of insulin content in $\beta$-cells; however, in the future these changes will gradually increase]

Diabetes caused by DZC is artificial and is used as a very good a pure model of diabetes, accompanied by death of $\beta$-cells only without alteration of other organs and tissues [68-70]. Diabetes caused by DZC is a type 1 diabetes (Figure 2). However, in this form in humans it practically does not occur. By the nature of the course, it like type 2 diabetes and develops gradually, with accumulation of XA in the body, in the most natural way described in the article, as is the case in humans [71-85]. Mean- while, XA-diabetes, caused by dietary disorders, on the contrary, is the most natural and real way of developing diabetes in humans, not induced by artificial injection of DZC.

\section{References}

1. Musajo S (1935) Aspects of disorders of kynurenine pathway of tryptophan metabolism in man. Atti Acad Lincei 21: 368-370.

2. Lepkovsky S, Roboz E (1943) Xanturenic acid and its role in the tryptophan metabolism of pyridoxin deficient rats. Nutrition Reviews 149: 195-201.

3. Kandori F, Fujinaga Y (1959) Studies of diabetic symptoms caused by xanturenic acid. Yonaga Acta Med 3:146.

4. Kotake Y (1957) Experiments of chronic diabetes symptoms caused by xantuenic acid, an abnormal metabolit of tryptophan. Clin Chem 3: 442-456.

5. Kotake Y, Inada T (1954) Effect of xanturenic acid upon glycogen content in liver, heart and sceletal muscle. J Biochem 4: 255-261.

6. Kotake Y, Tani S (1953) Studies of xanturenic acid: Xanturenic acid in the urine of diabetic patients. J Biochem 40: 295-298.

7. Kuno S (1960) Diabetic changes of pancreas in rats caused by deficiency of vitamin B6. Vitamins 1: 140-154.

8. Takaoka Y, Yamagushi N (1953) Studies of diabetic activity of xanturenic acid. Sashinigaku 11: 19-25.

9. Kotake Y, Inada T (1953) Studies of xanturenic acid. Preliminary report on xanturenic acid diabetes. J Bio Chem 40: 287-289.

10. Mason V (1956) Diabetes mellitus in animals. Diabetes 6: 486-489.

11. Davis R, Galder J (1976) Serum pyridoxal and folate concentration in diabetes. Pathology 2: 151-156.

12. Price J, Brown R (1957) Quantitative studies on human urinary metabolites of tryptophan as affected by isoniazid and deoxypyridoxine. J Clin Invest 36: 1600-1607.

13. Price S, West A (1960) Quantitative studies on human urinary metabolites of tryptophan as affected by isoniazid and deoxypyridoxine. J Pharmacol 10: 617-623.

14. Rubbo S, Albert A (1950) Studies of diabetogenic action of 8-oxyquinolin Brit J Exp Pathol 31: 425-428.

15. Zarman E, Barnes A (1955) Observation on pyridoxine metabolism in pregnancy. Amer J Gynecol 3: 645-649.

16. Kotake Y, Ueda T (1975) Abnormal tryptophan metabolism and experimental diabetes by xanturenic acid. $J$ Biochem 3: 685-687.
17. Takanashi H, Price J (1958) Dehydroxylation of xanturenic acid by 8-hydroxyquinaldic acid. J Biol Chem 233: 150-153.

18. Wiss G, Weber F (1964) Biochemical pathology of vitamin B6 deficiency. Vitam Horm 22: 495-501.

19. Glaser H, Mueller T (1951) Excretion of xanturenic acid by urine in rabbits contained on diet enriched by fats. Arch Biochem 33: 243-247

20. Voigt G (1957) Investigation for the human embryon pancreas. Acta Path Microbiol Scand 41: 81-88.

21. Montenero P (1960) Piridoxina e diabete arch stud physiopathol. Clin Ricamb 3: 285 289

22. Hattori M, Kotake Y, Kotake Y (1984) Xanturenic acid in the urine of patients with deficiency of vit B6. Acta Vit Enzymol 6: 221-228.

23. Crepaldi G, Allegri G (1975) Relationship between tryptophan metabolism and vitamin B6 and nicotinamid in aged subjects. Acta Vit Enzymol 29: 140-144.

24. Nakahara I, Watanabe Y (1961) Enzymatic studies on pyridoxine metabolism: The influence of fatty acid administration upon pyridoxin. J Biochem 49: 342-347.

25. Djioev F (1976) Study of the carcinogenic effect of tryptophan and some of its metabolites. 8-th Conference on Oncology. Leningrad 3: 41-42.

26. Knapp D, Veltishev Y, Barashnev I (1978) The role of metabolic disorders of tryptophan in the genesis of mental fatigue in children. Voprosi ochrani materinstva i detstva 10 : 51-56.

27. Knapp A,Wolfram J, Heilmann H (1967) Zur Pathologie des tryptophan stoffwefwechsels mit einem bericht uber eine weitere familie mit einer einen vitamin B6 mangel nachahmenden storung. Dt Gesund-heitswesen 12: 2449-2455

28. Okamoto K (1955) Experimental pathology of diabetes mellitus. Tohoku J Exp Med 3: $27-33$

29. Ranke A, Spellaey W (1977) Vitamin B6 treatment of gestational diabetes mellitus. Amer J Gynecol 6: 599-602.

30. Rose D, Toseland P (1973) Urinary excretion of quinolinic acid and other tryptophan metabolites after deoxypyridoxine or oral contraceptive administration. Metabolism 1973: 165-171.

31. Gillmer M, Mazibuko D (1979) Changes of tryptophan metabolism in pregnant women. Amer J Obstet Gynecol 5: 499-502.

32. Rose D, Braidman J (1971) Excretion of tryptophan metabolites as affected by preg nancy, contraceptive steroids and steroid hormones. Amer J Clin Nutr 6: 673-683.

33. Vandelli F (1951) Vitamin B6 metabolism in users oralcontraceptive agebts. Abnormal urinary xanturenic acid excretion and its correction by Pyridoxine. Amer J Clin Nutr 6: 684-693.

34. Wachstein G, Gudaitis F (1953) Disturbance of Vitamin B6 metabolism in pregnancy Clin Endocr Metab 12: 1207-1213.

35. Gorbacheva L (1989) The exchange of tryptophan along the kinurene and serotonin pathways in pregnant nephropathy. Akusherstvo I Gynecol 11: 16-20.

36. Coppini O, Comurri A (1954) Excretion of tryptophan metabolits as affected by pregnancy, contraceptive steroids and steroid hormones. Amer J Clin Med 6: 673-683. 
37. Rudzit V (1981) Diabetogenic metabolits of tryptophan. Riga.

38. Sharafetdinov H (1998) The content of vitamins in patients with insulin-dependent diabetes mellitus. Problemi of Endocrinologii 1: 13-15.

39. Avanesova T, Sviridova E (1980) The therapeutic activity of tryptophan and its effect on serotonin metabolism in patients. Neuropathology Psyhiatry 6: 857-863.

40. Алферова В, Раскин И (1962) Xanturenuria and the amount of vitamin B6 in the blood of patients with chronic hepatitis. Voprosi med chem 1: 20-22.

41. Meyramov GG, Kohnert KD, Meyramova AG (2001) About diabetic effects of Xanturenic acid. Problemi Endokrinologii 47: 39-44.

42. Meyramova AG (2003) Diabethogenic zinc-binding B-cytotoxic compounds. Problemi Endokrinologii 2: 8-16.

43. Kotake Y, Sotokawa Y (1968) Studies on the xanturenic acid-insulin complex. $J$ Biochem 5: 578-581.

44. Kotake Y, Kido R (1960) Research of Xanturenic acid: Inhibitory 4-hydroxy 8-metoxyquinolin-2carboxylic acid 8-methylether of xanturenic acid in rabbits. Proc Jap Acad 7: 439-444.

45. Weitzel G, Budecke E (1954) Zinkbind- ungsvermogen und blutzuckerwirkung von xanthurensaure, kynurenin und tryptophan. Hoppe-Seyler's Z Physiol 298: 169-184.

46. Markees S (1954) Untersuchungen zur frage gibt es einen xanturensaurediabetes. Helv Physiol Pharm Acta 4: 80-83.

47. Vanaga M (1957) Studies of diabetes caused by xanturenic acid. Wakayama Med Soc 4: $635-642$.

48. Kotake Y (1953) On the effects of xanturenic acid, a abnormal metabolite of tryptophan causing diabetic symptoms in the white rats. J Osaka Med School 14: 51-60.

49. Gandin-Harding F, Blum J (1964) De l'incapacite de reproduire les symptomes du diabete xanturenique. Arch Sci Physiol 1:49-58.

50. Okamoto H, Mijamoto S (1973) Insulin release effect of quinaldic acid and its relatives on isolated Langerhans islets. Biochem Biophys Res Com 8: 1297-1303.

51. Kotake Y, Sotokawa Y (1968) Physiological activity of Xanturenic Acid-8-MethylEther-Insulin complex. J Biochem 6: 895-896.

52. Mirsky I, Perisutti (1957) The hyperglycemic action of metabolic derivatives of L-tryptophan. Endocrinology 10: 318-324.

53. Takanashi H, Kaihara M (1956) The conversion of kynurenic acid to quinaldic acid by human and rats. J Biol Chem 223: 705-708.

54. Kotake Y, Kato T (1956) Inhibitory action of etheral sulfate of xanturenic acid and kynurenic acid with regard to its diabetogenic property. Proc Jap Acad 32: 361-363.

55. Kotake Y, Inada T (1953) Studies of xanturenic acid. Preliminary report on xanturenic acid diabetes. J Biochem 40: 291-294.

56. Kotake Y, Mori T (1955) On the excretion of xanturenic acid and the diabetic symptoms appeared in albino rats caused by vit.B6 deficiency. Proc Jap Acad 31: 247-251.

57. Meyramov G, Kohnert KD (1995) Studies of diabetogenic activity of xanthurenic acid. Bulletin Exper Biol Med 6: 669-672.

58. Kotake Y, Kato T (1956) Inhibitory action of etheral sulfate of xanturenic acid and kynurenic acid with regard to its diabetogenic property. Proc Jap Acad 32: 361-363.

59. Okamoto H, Mijamoto S (1974) Inhibitory effect of quinaldic acid on glucose-induced insulin release from isolated islets of the rats. Biochem Biophys Res Com 4: 623-628.

60. Kotake Y, Ueda T (1975) Abnormal Tryptophan metabolism and experimental diabetes by xanturenic acid. Acta Vitaminol Enzymol 29: 236-239.

61. Kotake Y, Murakami E (1971) A possible diabetogenic role for tryptophan metabolites and effects of Xanturenic Acid on insulin. Amer J Clin Nutr 7: 826-829.
62. Murakami Y, Kotake Y (1972) Studies on the Xanturenic Acid - Insulin Complex. $J$ Biochem 72: 251-259.

63. Murakami E (1964) Effect of Xanturenic acid onthe photooxidation of insulin by methylene blue. Jap Bio chem Soc 36: 829-834.

64. Murakami E (1968) Studies on the Xanturenic Acid-insulin Complex. J Biochem 63 573-577.

65. Murakami E (1975) Purification of Xanturenic Acid-Insulin complex. Acta Vitaminol Enzymol 29: 210-242.

66. Ikeda S, Kotake Y (1986) Urinary excretion of xanturenic acid and zinc in diabetes: occurence of xanturenic acid- $\mathrm{Zn}$ complex in urine of diabetic patients and experimental diabetic rats. Ital J Biochem 4: 232-241.

67. Kotake Y, Ueda T (1977) The interaction between Xanturenic Acid and insulin. 2nd International Meeting on tryptophan Metabolism 31.

68. Kotake Y, Nogami K (1954) Effect of 5-hydroxyantranylic acid on the formation and on its conjugating reaction of xanturenic acid in albino rats. J Biochem 41: 621-624.

69. Ueda T, Goda K (1977) The interaction between Xanturenic Acid - Insulin complex and Zinc ions. J Biochem 82: 67-72.

70. Albert A, Rubbo S (1947) Studies of the toxicity of chelat complexes of 8-oxyquinolin with Zn-ions. Brit J Exp Pathol 28: 69-70.

71. Meyramov GG, Coll (2013) Vascular and histological changes in pancreatic islets in diabetes caused by xanturenic acid. Diabetes 1: 751 .

72. Meyramov GG, Korchin VI (1998) Does diabetogenic activity of xanturenic acid determined by its chelating properties? Transpl Proceedings 30: 2682-2684.

73. Meyramov GG, Coll (2015) Histological changes in pancreatic islets of animals with experimental diabetes caused by xanthurenic acid under condition of supression of its endogenous synthesis. Bull Exp Biol Med 5: 680-684.

74. Meyramov GG, Kikimbaeva AA, Abikenova F (2000) Studies of mechanisms of diabetogenic action of xanturenic acid. Diabetes Res Clin Pract 50: 154-155.

75. Meyramov GG (1994) Protective Effect of glibenclamide on alterations induced in B-cells by Xanturenic acid. In b: 15th World Diabetes Congress, Kobe, Japan 438.

76. Meyramov GG, Meyramova AG (2000) Studies of diabetogenic activity of Xanthurenic acid. Diabetes 40: 429 .

77. Meyramov GG, Meyramova AG (2008) Death of human's pancreatic b-cells caused by xanturenic acid, a diabetogenic metabolit of tryptophan, started by destruction of b-granules. Diabetes 57: 728 .

78. Meyramov GG, Meyramova AG (2001) Interaction of Zn-ions With Na-salt of Diethyldithiocarbamic acid Protect B-cells of Alteration by Xanturenic Acid. Acta Diabetologica 4: 208-209.

79. Meyramov GG, Meyramova AG (2000) Studies of effect of xanturenic acid on pancreatic islets. Acta Diabetologica 3: 160.

80. Meyramov GG, Meyramova AG (2002) Zinc as cause of diabetes induced by chelators and as cause of its prevention. Diabetes 51: 591-592.

81. Meyramov GG, Coll (2009) Inhibition of synthesis of diabetogenic metabolites of tryptophan by pyridoxine. In b: 20th World Diabetes Congress, Montreal, Canada 430.

82. Meyramov GG, Coll (2011) Increasing of endogene synthesis of xanturenic acid 2 times not result destruction of pancreatic B-cells. Diabetes 60: 719.

83. Meyramov G.G. and coll. (2012) Effects of xanturenic acid on content of zn+2-ions in pancreatic b-cells. Diabetes 61: 735 .

84. Meyramov GG, Coll (2013) State of histostructure of liver in nimals with diabetes induced by xanthurenic acid. Diabetes 62: 720 .

85. Meyramov GG, Coll (2014) Differences of histological changes in pancreas in diabetes caused by synthetic and endogene formed xanthurenic acid. Diabetes 63: 669.

Copyright: $@ 2019$ Meyramov GG. This is an open-access article distributed under the terms of the Creative Commons Attribution License, which permits unrestricted use, distribution, and reproduction in any medium, provided the original author and source are credited. 